\title{
Competence units or holistic assessment: The language may be different but the challenges continue
}

\section{Clare Stone $e^{1}$}

\begin{abstract}
When public attention is focused upon the profession of social work, a typical response has been to change initial training and the learning outcomes by which students are assessed. Although social work education has employed competency frameworks for two decades the incompetence discourse and the concern about graduates' ability to undertake competent social work practice continues. Empirical research problematized the competence phenomenon to explore practice educators' experiences of using competency units and their perspectives of competence for social work. This paper draws upon findings from that research to explore the concept of holistic assessment and to suggest that educators need to reconsider the epistemological principles of assessment for social work practice.
\end{abstract}

Keywords: competency based education and training (CBET); holistic assessment; practice learning; competence for social work

1. Senior Lecturer. University of Central Lancashire. England.

Address for correspondence: Harrington HA314, School of Social Work, University of Central Lancashire, Preston PR1 2HE. Cstone2@uclan.ac.uk

44 J. of Practice Teaching \& Learning 13(1), pp.44-56. DOI: 10.1921/11302130102. @ w\&bb 2014 


\section{Introduction}

This paper draws upon findings from empirical research into practice educators' perspectives on the competence of students to practise social work. My professional experience as a social worker, practice educator, academic and researcher concur with the literature that competency-based education and training (CBET) has epistemological limitations for the assessment of social work practice. This paper commences with an overview of social work education in England to highlight how changes have been made to competence frameworks as a response to high profile child deaths. Although The College of Social Work promote a new culture of holistic assessment I urge educators to progress with care to ensure the focus is upon learning for professional practice rather than the activity on placement becoming the collecting of portfolio evidence. Insights generated through my research have relevance and importance for social work educators and other administrations in the UK and other country readers.

\section{The limitations of the competence approach for assessing social work}

Following the trajectory of social work education I have been able to make a link between high profile child deaths and changes to social work programmes and the learning outcomes by which students are assessed. The media reporting in the 'aftermath of child deaths' constructs a social worker discourse of failure which Westwood (2013) traces back to the death of Maria Colwell in 1973 (Westwood, 2013, p.139). Two years after the death of Maria Colwell the Certificate of Qualification in Social Work (CQSW) was introduced to provide a national standard for professional training. However, the inquiry into the death of Jasmine Beckford in 1984 concluded 'qualifying training in social work adjudged unfit for purpose' and this led to the CQSW being replaced by the Diploma in Social Work (DipSW) (Slater, 2007, p.750). The two year diploma was then replaced by a three-year degree level qualification in 2003 in 'response to political and public disquiet about the perceived quality of some social work practitioners' (Orme et al., 2009, p.162). This degree was replaced ten years later by the 2013 social work degree again as a response to high profile child deaths. The government funded a child protection review led by Lord Laming as a

45 J. of Practice Teaching \& Learning 13(1), pp.44-56. DOI: 10.1921/11302130102. @ w\&b 2014 
response to the media and public attention following the death of Victoria Climbié in 2000 (Laming, 2003). Seven years later came the equally high profile death of Peter Connelly which became 'a catalyst for public and government criticism of social work practice, management and training' (Bellinger, 2010b, p.2451). Peter Connelly's death 'ensured that social work and social work education became more of a government priority' (Mann, 2010, p.322). The Social Work Task Force (SWTF) appointed in 2008 (by the Secretaries of State for Health, and Children, Schools and Families) was tasked with reviewing the social work profession and they claimed that 'social work in England too often falls short of ... basic conditions for success' and included training as an area of weakness (SWTF, 2009, p.6). Although it is not possible within the scope of this paper to outline all of the changes since the CQSW (for example the number of placement days, target awards, curriculum guidance and validation criteria) I draw attention to the competency frameworks in which the social work students have been assessed over this period of time. The Central Council for Education and Training in Social Work (CCETSW) introduced competency-based education to social work via paper 30 in 1995 (O'Hagan, 2007, CCETSW, 1989). CCETSW's six core competences in the DipSW formed the basis for assessing a student's ability in practice learning placements until CCETSW was replaced by the General Social Care Council (GSCC) who introduced the six key roles of the National Occupational Standards for Social Work (NOS) (TOPSS, 2002). The 2013 social work degree has not one but two frameworks from two different bodies and these are further discussed below (TCSW, 2013b, HCPC, 2012b).

When public attention is focused upon the profession of social work, a typical response has been to change initial training and the learning outcomes by which students are assessed. Although social work education has employed competency frameworks for two decades the incompetence discourse and the concern about graduates' ability to undertake competent social work practice continues. For example The Social Work Task Force claimed that some students 'are being passed who are not competent or suitable for frontline social work' (SWTF, 2009, p.20). Laming recommended 'comprehensive inspection regime to raise the quality and consistency of social work degrees' (Laming, 2009, p.54). Munro (2011) agreed with those before her that 'not all newly qualified social workers are emerging from degree courses with the necessary knowledge, skills and expertise' (Munro, 2011, p.97). More recently Narey (2014) made recommendation for yet more change based upon his view that 'the preparation of students for children's

46 J. of Practice Teaching \& Learning 13(1), pp.44-56. DOI: 10.1921/11302130102. @ wE-b 2014 
social work is too often inadequate' (Narey, 2014, p.3). I problematized the competence phenomenon and researched CBET to understand how it is possible for a student to meet all of the competence units and graduate from initial training courses yet this does not necessarily give confidence that they will become a competent social worker.

CBET has been prominent in the UK since the mid 1960's and is popular because it develops workforce skills (Griffin, 1997). CBET is argued as being efficient on the premise that once the workforce has been trained and assessed as competent, they will 'perform expected behaviours' (Bogo et al., 2004, p.418). Usher (1997) explains that competency frameworks are seductive for both employee and employer because the learner feels empowered when they master the competencies and those same competencies become a means of regulation, control and performance management (Usher, 1997). As Eisner (1985) suggests CBET is appropriate for some occupations but there are three main concerns about using CBET for professional social work education (Eisner, 1985). First, social work practice cannot be broken down into easily described objectives (Page and Knight, 2007, Cree, 2003, Beverley and Worsley, 2007). Second, CBET primarily focuses on skills whilst knowledge and values attract little or no attention (Barnett, 1994, Griffin, 1997). The third concern about CBET is that some aspects of competence cannot be measured directly by observing the student's performance (Lum, 2004, Eraut, 1994, Barnett, 1994).

Writing about generic education, Lum (2004) suggests that competency frameworks require unambiguous and specific description of competence otherwise they are flawed (Lum, 2004). As Page and Knight (2007) explain some aspects of competence resist definition and this is certainly the case with social work (Page and Knight, 2007). Social work practice is difficult to define as social work has many facets with no unanimity in either literature or in social workers' own accounts of what they do (Cree, 2003). Social workers practise within a range of settings with different client groups all with unique situations and challenges. It is my experience that social workers themselves find it difficult to explain what they do and Thompson (2000) captures the ambiguity of social work practice when he writes that 'social work is what social workers do' (Thompson, 2000, p.13). Cree (2013) suggests 'there is no essential social work task' rather it is a 'collection of competing and contradictory discourses' framed within a 'particular moment in time' (Cree, 2013, pp.4-5). As social work practice is difficult to define, fluid and ever changing then there is arguably reason to have little confidence that a student who meets the entire competency

47 J. of Practice Teaching \& Learning 13(1), pp.44-56. DOI: 10.1921/11302130102. @ wEbb 2014 
framework should be competent for social work practice. Furness and Gilligan (2004) support this view, reporting that practice educators have experience of students meeting the defined competencies yet they 'remain uneasy about that individual's fitness for practice' (Furness and Gilligan, 2004, p.469). Bilson $\&$ Ross (1999) agree than an educator can tick all of the competency boxes but a student may lack ability to 'carry out good and sensitive social work practice' (Bilson and Ross, 1999, p.158). This is possibly because the competencies focus attention on the 'minutia and a loss of appreciation of the whole' (Beverley and Worsley, 2007, p.65). Therefore, if the competence learning outcomes do not define competent practice, the assessment cannot be relied upon that the student is safe and competent for social work practice.

Preston-Shoot (2000) suggests that the contradictions, dilemmas and tensions in social work practice are lost in CBET as competencies focus on outputs that are easy to measure (Preston-Shoot, 2000). Biggs and Tang (2007) advise that:

the technician does what he does because he has been trained to do it: the professional does what she does because she has thought about it and made an informed decision to do it this way and not that way. (Biggs and Tang, 2007, p.136)

A professional such as a social worker needs to think about the options available, draw upon experience and knowledge, and select an appropriate course of action however the competency approach 'does not facilitate the theoretical, analytic and reflective skills needed for the work' (McNay et al., 2009, p.89). Alongside practical skills social workers also require creativity and critical thinking (Page and Knight, 2007). Bogo et al. (2006) use the term 'metacompetencies' to cover creativity, mental agility, learning skills, problem-solving and analytical capabilities. Metacompetency refers to all of those abilities within knowledge and understanding, which are essential for the professional who is required to make informed decisions in their day to day practice. The social worker or indeed student, must draw upon theoretical knowledge, use observational skill, and analyse environmental and relationship factors. They then need mental agility to process all of those variables against laws, guidance and policy, and at the same time consider principles of ethical practice. Munro (2011) states that social workers 'need formal training and high intelligence to achieve the level of critical reasoning needed to make sound judgments and decisions

48 J. of Practice Teaching \& Learning 13(1), pp.44-56. DOI: 10.1921/11302130102. @ wE-b 2014 
on the complex family problems they confront' (Munro, 2011, p.86). Metacompetency is difficult to describe within instrumental competencies and has been underrepresented in the assessment frameworks used in social work education. It is my experience that some students struggle with mental agility yet they consider themselves to be competent as they can provide evidence of meeting all of the tasks required to construct a portfolio.

A traditional approach in CBET is to assess performance; however, knowledge, reflection, values and personal attributes cannot be assessed simply by watching but may be inferred in behaviour or as a consequence of behaviour (Lum, 2004). The assessment task becomes complex when the practice educator must look beyond performance and also consider capability evidence such as written work and discussion in supervision (Eraut, 1994, Barnett, 1994). The person assessing must formulate a holistic view by looking at direct performance and other evidence of capability.

Holistic learning and assessment.

The student needs to underpin skilled performance with social work knowledge and values and the person assessing needs to look beyond behaviour for actual capability and potential. Student social workers need to make sense of the situations they are faced with and synthesize knowledge, values and skills to make a coherent whole (Bilson and Ross, 1999). Furness and Gilligan (2004) use the term 'across the board' to distinguish the coherent whole from competence against individual instrumental units (Furness and Gilligan, 2004, p.469). This type of synergised fluid social work practice has been described as; the 'multiple dimensions of social work practice' (Bogo et al., 2002, p.388); 'practice wisdom' (Schön, 1991, p.21); 'creative practice' (Bellinger, 2010a, p.602); 'professional maturity' (Eraut, 1994, p.40) and 'tacit knowledge' (Bogo et al., 2004, p.418). It is not possible to give a technical instrumental instruction of how to do practice wisdom or artistry as social work practice is fluid, ever-changing and context specific:

Social work is inevitably defined by the social contexts in which it is practised and therefore requires practitioners who are able to respond to these everchanging social contexts with knowledge, skills and professional integrity. (McNay et al., 2009, p.89)

In a fast moving profession such as social work one cannot predict what knowledge or skills will be required for future practice so moving beyond prescribed competencies to transferable capability is desirable (Barnett,

49 J. of Practice Teaching \& Learning 13(1), pp.44-56. DOI: 10.1921/11302130102. @ wEbb 2014 
1994, Orme et al., 2009). The new Professional Capability Framework (PCF) comprises nine domains that outline capability from the point of entry to social work programmes, through initial training and into practice to support continued professional development (TCSW, 2013b). To assess against the PCF one does not look for instrumental evidence and tick off individual statements, rather the focus is on holistic assessment and holistic capability (Keating, 2012; Woodham, 2012). This is achieved by considering the PCF domains as interconnected and mutually supported. The College of Social Work promoted the PCF as a new culture of assessment; however, it is my interpretation that practice educators already assess holistically and they do this in a multi-dimensional manner (Stone, 2014). Rather than just looking across the domains to assess capability their holistic assessment considers three further directions:

1. Practice educators consider every placement experience to be an assessment opportunity and begin their assessment at the preplacement meeting before the placement commences. They make formative assessments continuously throughout the placement to monitor the student's development. The practice educators use a range of evidence including performance such as direct observations and team meetings, and capability evidence such as discussion in supervision and written work.

2. Practice educators embrace a wider range of perspectives within the assessment process and obtain feedback from all placement stakeholders including service users, carers, team members, managers and other professionals throughout the practice learning period.

3. The third way that practice educators assess holistically is that they see initial training as the first part of the individual's social work career. The practice educators look beyond the immediate placement requirements to give the student the best opportunity they can to succeed, not only to pass the placement but to become an effective practitioner.

\section{Holistic assessment: A note of caution}

Although assessment against individual competencies has been criticised, lists of units do help practice educators to structure the learning experiences and are useful to benchmark student progress (Stone, 2014).

50 J. of Practice Teaching \& Learning 13(1), pp.44-56. DOI: 10.1921/11302130102. @ w\&-b 2014 
It is my suggestion that the practice curriculum outlined in the Practice learning guidance. Placement criteria ought to receive more prominence and be used as a framework for formative and summative assessment: particularly during the final placement (TCSW, 2013a). However, the practice curriculum must not be viewed as instrumental tasks to tick off but ought to be considered as the foundation of professional practice requiring the synergy of knowledge, skills, values and characteristics required for professional practice.

Assessing holistic practice 'requires a hermeneutic judgement' where the educator must interpret the evidence before them (Biggs and Tang, 2007, p.184). Bloxham (2011) suggests that the lot of complexities are taken into account to form an overall holistic judgement and to do this the educator uses tacit knowledge measured against 'subliminal internalised standards' (Bloxham, 2011). Riebschleger and Grettenberger (2006) agree advising that in the practice placements the practice educator has 'implicit criteria' (Riebschleger and Grettenberger, 2006, p.188). The practice educator looks at the 'unique properties' of the student using their 'experience and sensibilities' to make a human qualitative judgement' (Eisner, 1985, p.34). The internalised criteria shape the educator's opinion about a student's competence but unfortunately some competencies that educators value resist definition (Page and Knight, 2007).

In my research very experienced practice educators found it difficult to articulate competent social work practice (Stone, 2014):

I think there's still something about um that can't be written down ... its um unquantifiable bit which I can't, clearly can't write down. But you can tell often whether someone is going to make a good social worker or not ... Just its that indefinable quality that some people have ... had that extra whatever it is that I can't put my finger on. (Participant Hazel)

We can tick all the boxes as it were but, when you've got little niggles about somebody ... because the competencies are set out at a basic level, you couldn't, you could say that they were meeting but there's just something that you just can't get hold of. (Participant Alice)

I think there's a lot of it in [NOS] but sometimes you can't put your finger why somebody's not right, you can't actually say why somebody's not working but I've seen ... (Participant Liam)

51 J. of Practice Teaching \& Learning 13(1), pp.44-56. DOI: 10.1921/11302130102. @ wEb 2014 
If those doing the assessing find competence a difficult concept, I wonder how a student understands what is expected of them. It is my suggestion that it is relatively straightforward to record holistic achievement with the more able student but practice educators may experience difficulty in articulating their internalised hermeneutic judgement when the student is underachieving and failing to perform holistic synergised practice. Therefore, the practice educator needs to be clear about what is good enough and evidence must be reliable, sufficient, fair, clear and valid (Furness and Gilligan, 2004).

Another consideration for those within the practice learning community is that the 2013 degree has not one competency framework but has two different standards from two different bodies. The College of Social Work has produced the Professional Capabilities Framework (PCF) and the Health and Care Professions Council has the Standards of Proficiency (SOP) which graduates must meet to be eligible to enter the social work register. Taylor and Bogo (2013) suggest there is a 'fault line' between these two frameworks with the potential to develop 'into a perfect storm of catastrophic outcomes' (Taylor and Bogo, 2013, p.14). They suggest this is because the SOP is concerned with threshold level competence whereas the PCF was originally designed to be aspirational and not intended to be used as assessment criteria. It is important therefore for universities to offer clarity in how these two new frameworks are to be used together. The BA (Hons) Social Work Programme at University Campus Suffolk piloted the PCF and SOP in the academic year 2012-13 and reported that all stakeholders required additional support as they begin to use the new frameworks and regular workshops helped develop understanding and confidence (Plenty and Gower, 2013).

A concern relevant to assessment against units of competence is that the collecting of evidence can become the placement activity rather than the focus being on learning experiences (McNay et al., 2009). Given that the units within the new frameworks are extensive (the SOP alone has 76 units) collecting evidence for all of these can dominate the placement experience. To ensure best possible outcomes, the student's placement activity and assessment must 'focus upon the 'doing' of social work' (Simpson and Murr, 2013, p.132). This is particularly important as alongside the PCF and the SOP there is also the practice curriculum and the Guidance on Conduct and Ethics (GCE) (HCPC, 2012a, TCSW, 2013a). Therefore the assessment frameworks and documentation that HEIs develop to evidence capability must offer structure but not become the main focus of the placement. The

52 J. of Practice Teaching \& Learning 13(1), pp.44-56. DOI: 10.1921/11302130102. @ wE-b 2014 
HEI has responsibility to ensure that there are clear procedures in place; the assessment focuses on the student's capability to do competent social work (not capability to collect evidence); and that assessments draw upon the language of the PCF, SOP and GCE but is not driven by them.

\section{Conclusion}

High profile child deaths have focused public attention onto the social work profession and a typical response has been to amend initial training and the units of competence by which students are assessed. Despite changing the competency frameworks the discourse of incompetence in the profession continues to the present day. This paper has explored three main concerns about the use of competency frameworks and suggests that despite the fanfare of holistic principles educators need to reconsider the basic epistemological principles of assessment. Social work is difficult to define because it is context specific, complex and ever changing. Educators need to accept that assessment involves hermeneutic judgement based on internalised standards that may be difficult to articulate but to use the words of one research participant 'you know it when you see it' (Stone, 2014). Practice educators need confidence in their intuition to ensure that only those students who have social work knowledge, skills, values and the characteristics for social work are allowed to pass. Universities must work to support practice educators in their gatekeeping role and regardless of the frameworks used, students must be assessed on capacity for social work practice.

\section{References}

Barnett, R. (1994) The Limits of Competence: Knowledge, higher education and society. Open University Press

Bellinger, A. (2010a) Studying the landscape: Practice learning for social work reconsidered. Social Work Education, 29, 599-615

Bellinger, A. (2010b) Talking about (re)generation: Practice learning as a site of renewal for social work. British Journal of Social Work, 40, 2450-2466

Beverley, A. and Worsley, A. (2007) Learning and Teaching in Social Work Practice.

53 J. of Practice Teaching \& Learning 13(1), pp.44-56. DOI: 10.1921/11302130102. @ w\&b 2014 
Basingstoke, Palgrave Macmillan

Biggs, J. and Tang, C. (2007) Teaching for Quality Learning at University: What the Student Does. (3rd ed) Buckingham, Open University Press

Bilson, A. and Ross, S. (1999) Social Work Management and Practice: Systems principles. London, Jessica Kingsley

Bloxham, S. (2011) Understanding the rules of the game: Helping students really graps what we are looking for when we mark. UCLan seminar

Bogo, M., Regehr, C., Hughes, J., Power, R. and Globerman, J. (2002) Evaluating a measure of student field performance in direct service: Testing reliability and validity of explicit criteria. Journal of Social Work Education, 38, 385-401

Bogo, M., Regehr, C., Ppower, R., Hughes, J., Woodford, M. and Regehr, G. (2004) Toward New Approaches for evaluating student field performance: Tapping the implicit criteria used by experienced field instructors. Journal of Social Work Education, 40, 417-426

CCETSW (1989) Requirements and Regulations for the Diploma in Social Work. [CCETSW Paper 30] London: Central Council for Education and Training in Social Work

Cree, V. E. (2003) Becoming a Social Worker. London: Routledge

Cree, V. E. (2013) Becoming a Social Worker. Global Narratives., 2nd Edition. Abingdon, Routledge

Eisner, E. W. (1985) The Art of Educational Evaluation: A personal view. London: Falmer

Eraut, M. (1994) Developing Professional Knowledge and Competence. [electronic resource] London: Falmer

Furness, S. and Gilligan, P. (2004) Fit for purpose: Issues from practice placements, practice teaching and the assessment of students' practice. Social Work Education, 23, 465-479

Griffin, A. (1997) Knowledge under attack: Consumption, diversity and the need for values. in R. Barnett and A. Griffin (Eds.) The End of Knowledge in Higher Education. London: Cassell

HCPC (2012a) Guidance on Conduct and Ethics for Students. London: Health and Care Professions Council

HCPC (2012b) Standards of proficiency. Social work in England. London: Health and Care Professions Council

Keating, M. (2012) From NQSW to ASYE - Preparing for Implementation. Social Work Reform: Ambition to Reality (Presentation at 'Social Work Reform: Ambition to Reality' Conference, Leyland Preston, 1st March 2012)

Laming, H. B. (2009) The Protection of Children in England: A progress report. London: Stationery Office

54 J. of Practice Teaching \& Learning 13(1), pp.44-56. DOI: 10.1921/11302130102. @ w\&bb 2014 
Laming, L. (2003) The Victoria Climbie Inquiry. Cm 5730. London:The Stationery Office

Lum, G. (2004) On the non-discursive nature of competence. Educational Philosophy and Theory, 36, 485-496

Mann, T. (2010) Personal reflections of social work education in the context of the Social Work Task Force. Practice, 22, 321-329

McNay, M., Jean, C. and Lovelock, R. (2009) The journey towards professionalism in social work: The development and assessment of practice learning. Journal of Practice Teaching in Health and Social Work, 9, 72-91

Munro, E. (2011) Munro Review of Child Protection: Final Report. A Child-centred System. London: Dept for Education

Narey, M. (2014) Making the Education of Social Workers Consistently Effective. www. gov.uk/government/publications. London: Department for Education

O'Hagan, K. (2007) Competence in social Work Practice: A practical guide for students and professionals. London : Jessica Kingsley

Orme, J., MacIntyre, G., Lister, P.G., Cavanagh, K., Crisp, B.R., Hussein, S., Manthorpe, J., Moriarty, J., Sharpe, E., and Stevens, M. (2009) What (a) difference a degree makes: The evaluation of the New Social Work Degree in England. British Journal of Social Work, 39, 161-178

Page, A. and Knight, P. (2007) Assessing 'wicked' competences. Educational Developments. SEDA, 8.3

Plenty, J. and Gower, D. (2013) The reform of social work practice education and training and supporting practice educators. Journal of Practice Teaching and Learning, 12, 2, 48-66

Preston-Shoot, M. (2000) Stumbling towards oblivion or discovering new horizons? Observations on the relationship between social work education and practice. Journal of Social Work Practice, 14, 87-98

Riebschleger, J. and Grettenberger, S. (2006) Assessing graduating BSW field students' preparation for generalist practice. The Journal of Baccalaureate Social Work, 12, 184-202

Schon, D. A. (1991) The Reflective Practitioner: How professionals think in action Aldershot : Ashgate

Simpson, G. and Murr, A. (2013) The 'not yet competent' student. The Journal of Practice Teaching and Learning, 11, 3, 118-134

Stone, C. (2014) An Exploration of How Practice Educators Use Competency Frameworks to Assess Social Work Students in Practice Learning Setting.s Doctoral Thesis. Preston: University of Central Lancashire

SWTF (2009) Building a Safe, Confident Future. The final report of the Social Work Task Force

55 J. of Practice Teaching \& Learning 13(1), pp.44-56. DOI: 10.1921/11302130102. @ w\&b 2014 
Taylor, I. and Bogo, M. (2013) Perfect opportunity - perfect storm? raising the standards of social work education in England. British Journal of Social Work, Advance Access published November 13, 2013, 1-17

TCSW (2013a) Practice Learning Guidance. Placement criteria (edref9). [Online]. http:// www.collegeofsocialwork.org/uploadedFiles/TheCollege/_CollegeLibrary/ Reform_resources/PlacementCriteria(edref9).pdf: The College of Social Work. [Accessed 08/02/2013]

TCSW. (2013b) The Professional Capabilities Framework. [Online]. http://www. collegeofsocialwork.org/: The College of Social Work. [Accessed 08/02/2013]

Thompson, N. (2000) Understanding Social Work: Preparing for practice . [electronic resource] :Aldershot: Macmillan

TOPSS (2002) The National Occupational Standards for Social Work. England: TOPSS

Usher, R. (1997) Seductive texts: competence, power and knowledge in postmodernity. in R. Barnett and A. Griffin (Eds.) The End of Knowledge in Higher Education. London: Cassell

Woodham, G. (2012) Skills for Care and CWDC Presentation: Update on the Skills for Care and CWDC social work programme. (Presentation at 'Social Work Reform: Ambition to Reality' Conference, Leyland Preston, 1st March 2012)

56 J. of Practice Teaching \& Learning 13(1), pp.44-56. DOI: 10.1921/11302130102. ๑) w\&b 2014 